\title{
Zasada preferencji zadań mierzalnych, czyli dlaczego organizacje bywają na ogół bardziej trywialne w rzeczywistości niż w teorii
}

https://doi.org/10.33141/po.2005.10.03

Krzysztof Łobos
Przegląd Organizacji, Nr 10 (789), 2005, ss. 16-19 www.przegladorganizacji.pl Towarzystwo Naukowe Organizacji i Kierownictwa (TNOiK)

\section{Wprowadzenie}

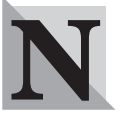

iewiele jest w teorii organizacji i kierowania uogólnień, które można uznać za powszechnie przyjmowane i jednocześnie takie, które z bardzo dużym prawdopodobieństwem realizują się w praktyce. Na ogół konstatacje w ramach tego obszaru wiedzy nie posiadaja mocy predykcyjnej. Systemy społeczne, w tym organizacyjne, uznajemy za tak niezwykle złożone, że aż w praktyce nieprzewidywalne. Celem artykułu jest ukazanie jednej z realnych „zasad” w nauce organizacji i kierowania oraz konsekwencji z niej wynikających dla codziennej praktyki organizacyjnej.

\section{Zasada preferencji zadań mierzalnych}

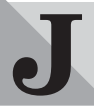
ednym $\mathrm{z}$ wyjątkowych $\mathrm{w}$ tym względzie stwierdzeń jest to dotyczące preferencji w zakresie realizacji różnego typu zadań przez ich wykonawcę. Może być ono sformułowane następująco: jeśli wyróżnimy klasę zadań o wyniku trudno mierzalnym bądź niemierzalnym oraz klasę zadań o wyniku mierzalnym i stwierdzimy, że obydwie zostały przyporządkowane do realizacji jednemu podmiotowi, to zadania $\mathrm{z}$ wynikiem wymiernym będą realizowane w pierwszej kolejności, a nawet kosztem zadań z wynikiem niewymiernym (słabo wymiernym) ${ }^{1}$. Obserwacja rzeczywistości organizacyjnej skłania do konstatacji, że teza ta jest nieomal prawem. Powody zjawiska są proste w odróżnieniu od większości innych zjawisk organizacyjnych: przełożeni są w stanie dokładnie skontrolować wyniki mierzalne, a więc i wykonawca dba o efekty możliwe do skontrolowania, od których zależy (w znacznej mierze) ocena jego pracy. „Prawo” obowiązuje na wszystkich szczeblach organizacji, każdy z nich posiada bowiem swój organ kontrolny. Dotyczy ono nawet top managementu, który, oprócz rad nadzorczych, jest pod naciskiem interesariuszy. Wymierne wyniki, którymi muszą się legitymować, aby trwać w organizacji na kluczowym stanowisku, są podstawową ich troską. Na dalszy plan schodzą w tej sytuacji działania bez efektów wymiernych w krótkim horyzoncie. To samo dotyczy szere- gowej księgowej czy magazyniera. Nie współtworzenie kompleksowego systemu kontrolingu, lecz oddanie sprawozdań na czas bądź bezbłędne wypisanie dokumentów magazynowych jest ich najważniejszym zadaniem. Do bardziej rozmytych powodów preferencji zadań wymiernych należy, zdaniem autora, również podświadome traktowanie wymierności jako bardziej wartościowej od niewymierności.

\section{Organizacyjne implikacje zasady}

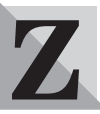

asada preferencji zadań z wynikiem wymiernym posiada, zdaniem autora, wiele bardzo konkretnych implikacji praktycznych, daleko wykraczających poza prostą kolejność realizacji dwóch opisanych typów zadań. Pozwalają one pokazać, dlaczego część wysiłków organizatorskich czy związanych z pewnymi koncepcjami zarządzania tak naprawde kończy swój żywot na papierze (w najlepszym razie), bądź jako nieudane, lecz kosztowne i zniechęcające wdrożenie (w najgorszym). Pozwala pokazać również, dlaczego organizacje są na ogół o wiele bardziej trywialne i sztampowe niż wydaje się to z punktu widzenia teorii organizacji i kierowania. Wymieńmy więc najistotniejsze implikacje praktyczne omawianej zasady.

- Organizacje są w zdecydowanej większości systemami autokratycznymi (i hierarchicznymi), a nie demokratycznymi (i heterarchicznymi). Demokratyzacja życia organizacyjnego, mimo że teoretycznie pożyteczna, należy do zjawisk marginalnych, gdyż jej wprowadzanie, wiążące się nierozłącznie z partycypacją, tworzy zamęt organizacyjny, rodzi znaczne potrzeby w zakresie działań koordynacyjnych (spotkania, opracowywanie ich efektów), a efekty partycypacji rzadko bywają wymierne. Idzie się więc „na skróty”, a czas przeznacza raczej na realizację wyznaczonych zadań wymiernych.

- Organizacje rzadko wprowadzają w życie „miękkie” metody i techniki zarządzania. Większość modelowych ujęć metod i technik zarządzania przeładowana jest postulatami działań, które nie rodzą wymiernych efektów. Szacowanie pola sił zmiany (zarządzanie zmianą), tworzenie map wiedzy (zarządzanie wiedzą), iden- 
tyfikowanie i uświadamianie istnienia problemów pracowniczych (counselling), bądź nawet bieżące monitorowanie organizacji wewnętrznej przedsiębiorstwa (zarządzanie przez formalizację), to przykłady działań z różnych metod i technik, które sa przytłaczane przez codzienność wymiernych prac. W praktyce zarządzania ostają się więc tylko te metody, które mają bezpośredni związek z wymiernymi efektami, np. outsourcing, just in time (wpływ na poziom kosztów), zarządzanie przez wyniki, zarządzanie przez cele (stymulowanie wzrostu efektywności), metody badania pracy (kształtowanie systemu wynagrodzeń, wpływ na wielkość zatrudnienia). Metody te ostaja się w praktyce w najprostszej, okrojonej z działań niewymiernych postaci. Często także naturalne działania podejmowane $\mathrm{w}$ organizacjach nazywane sa metoda.

- Organizacje niezwykle rzadko posiłkują się w procesach wdrażania metod i technik, planowania oraz podejmowania decyzji tzw. racjonalną procedurą. Racjonalne procedury w odniesieniu do skomplikowanych sytuacji są swoistym „siedliskiem” działań niewymiernych, a nawet pozornych, czyli tych, które redukuje praktyka organizacyjna. Przykładowo, procedura racjonalnego wdrożenia decyzji zawierać powinna takie elementy, jak: poszukiwanie informacji, kontrola kompletności i wiarygodności informacji, formułowanie alternatyw, formułowanie kryteriów oceny, ocena na podstawie kryteriów, ocena prawdopodobieństwa realizacji, a wreszcie wybór. Praktyka podejmowania decyzji dowodzi jednak, że częstszy jest inny proces. Decydent lub mała ich grupa na podstawie intuicji i wcześniejszych doświadczeń upiera się przy określonym rozwiązaniu, lansuje je za wszelką cenę, prezentując wyłącznie zalety. Alternatywy nie są brane pod uwagę i jest to raczej zaleta niż wada, gdyż upór i konsekwencja w dążeniu do obranego celu często determinują skutecznośćc ${ }^{2}$.

- Organizacje korzystają najczęściej ze wzorców już wypracowanych. Wypracowywanie jakościowo nowych rozwiązań w sferach takich, jak organizacja czy strategia jest rzadziej obecne w praktyce niż świadome bądź też nie kopiowanie. Po pierwsze, efekty wprowadzania jakościowo nowych rozwiązań w wyżej wymienionych sferach są bardzo trudne do oszacowania. Brak jest więc motywacji do podjęcia trudu innowacji i „wyważania drzwi” na nowo. Po drugie, w natłoku wymiernych działań bieżących o wiele skuteczniejsze jest kopiowanie rozwiązań już istniejących. Samo otoczenie podpowiada nam ten skądinąd skuteczny sposób postępowania. Kopiowanie rozwiązań organizacyjnych dokonuje się na podstawie wzorców organizacji osiągających sukcesy rynkowe. Zakłada się więc, że są one racjonalne ${ }^{3)}$. Podobnie jest ze strategią. Nie opracowanie kompletnie odmiennego wzorca zachowania w branży, lecz raczej zrozumienie jej logiki prowadzi do sukcesu ${ }^{4}$. Powyższe stwierdzenia sugerują pewne ograniczenie roli kadry kierowniczej wyższego szczebla jako decydenta organizacyjnego i kreatora polityki względem otoczenia. Ograniczenia zewnętrzne oraz czasowe powodują, że nawet kadra wyższego szczebla częściej niż kreatorem jest administratorem i podmiotem usiłującym dopasować organizację do ograniczeń otoczenia i zinstytucjonalizowanych wzorców.
Niewymierne zadania realizowane w praktyce pojawiają się w okresach koniunktury bądź są związane $\mathrm{z}$ realizacją pewnej polityki organizacyjnej w kontekście słabości bądź nieobecności nadzoru właścicielskiego. Wówczas to usankcjonowana może zostać nieefektywność działań. W słabych ekonomicznie firmach często podejmuje się próby sanacji. Warto zwrócić jednak uwagę na fakt, że działania w ramach takich programów, to działania z wymiernym efektem. Outsourcing, zwolnienia, ograniczanie administracji, zwalnianie pomieszczeń, redukcja kosztów, to działania najbardziej typowe. W sytuacjach kryzysowych nikt nie podejmuje się zarządzania wiedzą, zarządzania przez grupy samosterujące czy zarządzania przez delegowanie uprawnień. Stanowi to, zdaniem autora, argument na rzecz hipotez postawionych wyżej.

\section{Ograniczenia stosowalności zasady}

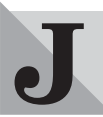

ak zostało to zasygnalizowane wyżej, część organizacji pokazuje w praktyce, że wdraża w sposób mniej lub bardziej udany naszpikowane zadaniami niewymiernymi koncepcje bądź metody czy techniki zarządzania w życie. Znane są nawet, choć bardzo nieliczne, eksperymenty polegające na budowaniu organizacji prawie w pełni demokratycznych ${ }^{5)}$. Można także podawać przykłady firm, które tworzą własne strategie rynkowe, a nie dopasowuja się do logiki branży. Czasami nawet strategie te okazują się trafione. W jakich warunkach może więc dochodzić do kreowania innowacji w zakresie organizacji i zarządzania oraz realizowania zadań uważanych za zadania z niewymiernym efektem?

Po pierwsze, stwierdzić należy, że krytycznym czynnikiem moderującym system zarządzania przedsiębiorstwa jest jego sytuacja ekonomiczna. Firmy wykazujące dobrą kondycję ekonomiczną i których kadra kierownicza przekonana jest o dobrych perspektywach rozwojowych, rosną tak ze względu na wartość majątku, jak i zatrudnienie. Nie występuje presja na redukcję kosztów. Takie tendencje pokazuja menedżerskie teorie przedsiębiorstwa, według których naczelnej kadrze zależy na wzroście wartości przedsiębiorstwa, jego wielkości, obrocie, a nie na $\mathrm{zysku}^{6}$. W dużym obrocie realizowanym przez wielką organizację łatwiej jest bowiem ukryć wszelkiego typu wydatki mniej racjonalne bądź nieracjonalne. Kadra kierownicza wyższego szczebla wykazuje też skłonności do hojnego gospodarowania środkami pozostającymi do jej wyłącznej dyspozycji. Racjonalność pozostaje wówczas na drugim planie. Opisana sytuacja stwarza doskonały grunt do nadmiernego zatrudnienia oraz podejmowania działań nie mieszczących się w kategorii działań z wymiernym efektem. Przyczynia się również do tego intensywny konsulting, na który opisaną grupę firm po prostu stać. Sytuację tę można podsumować następująco: dobra sytuacja ekonomiczna i perspektywy rozwojowe prowadzą do wzrostu liczby działań niewymiernych i wpływają na system zarządzania przedsiębiorstwem. Dlatego też firmy „dobre”, częściej niż słabe, posiadają „nowoczesny” system zarządzania. Zdaniem autora znaczna część działań z niewymiernym efektem jest również mało racjonalna. Dlatego też raczej „dobre” firmy mają „nowoczesny” 
system zarządzania niż „nowoczesny” system zarządzania determinuje kreacje „dobrej” firmy. Część trafionych działań z niewymiernym efektem jedynie zwrotnie wspiera racjonalność bądź podnosi motywację załogi do pracy.

Czasami jednak nawet w bardzo słabych ekonomicznie przedsiębiorstwach wdrażane sa programy zawierające mnóstwo działań $\mathrm{z}$ efektem niewymiernym. Można z dużym prawdopodobieństwem stwierdzić, że polityka organizacyjna rozumiana raczej pejoratywnie odgrywa $\mathrm{w}$ tym procesie podstawową rolę. Menedżerowie nie mogąc wykazać się realnymi efektami ekonomicznymi, wynikami, poszukuja innych źródeł legitymizacji. Jeśli określone działania, opisane zbiorczo jako $\mathrm{np}$. reengineering, uważane sa za nowoczesne, to realne czy pozorne próby ich implementacji pokazują bliższemu otoczeniu, że działa się na rzecz osiąnięcia wyższej efektywności. Rzecz jasna w grupie politycznych motywacji podejmowania tego typu działań są też interesy partykularne kadry kierowniczej. Przykłady są powszechnie znane z praktyki. Brak realnego nadzoru właścicielskiego w wielu polskich przedsiębiorstwach, szczególnie w dobie transformacji prowadził i prowadzi do nasilania się procesów wykorzystywania pozycji kierowniczej do własnych celów ${ }^{7}$.

Część działań określonych na początku artykułu jako działania bez efektów wymiernych jest podejmowana w praktyce i posiada pozytywny wpływ na przyszłość organizacji. Część ta ma jednak realny charakter i nie jest jedynie pozorowaniem działań. Pozwalają na nie sobie, jak zostało to stwierdzone wyżej, organizacje wykazujące dobrą kondycję ekonomiczną. Do działań takich należą przykładowo analizy i badania rynkowe, prace badawczo-rozwojowe, prace nad doskonaleniem organizacji przedsiębiorstwa czy szkolenia i doskonalenie zawodowe.
Modelowy układ zależności przedstawiający zjawisko narastania liczby działań z efektem niewymiernym i jego wpływ na efektywność organizacyjną ukazuje rysunek. Zależności realizujące się w krótkim okresie pokazano strzałkami ciagłymi, długim - przerywanymi. Układ zależności posiada sprzężenie zwrotne umożliwiające zachowanie równowagi. Nie oznacza to jednak bezwarunkowo konieczności utrzymania istnienia organizacji, bądź tym bardziej stabilności relacji własnościowych. Układ może zostać rozregulowany, na przykład wskutek braku działań restrukturyzacyjnych, czego efektem jest kryzys organizacyjny, a nawet zagrożenie ciągłości funkcjonowania. W kontekście zjawiska narastania liczby zadań niewymiernych rozpatrywana jest efektywność organizacji. Realizacja zadań z efektem niewymiernym, pozornych czy realnych, nie jest jednak, co należy podkreślić, podstawowym czynnikiem determinujacym tę efektywność. Przykładem determinanty silniejszej jest uwzględnione na rysunku otoczenie branżowe.

\section{Czy działania bez mierzalnych efektów, w tym miękkie metody i techniki mają w ogóle jakiś sens?}

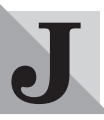

eśli dokonamy podziału zadań z efektem niemierzalnym na celowe i pozorne, to sprawa wydaje się być oczywista. Zadania te mają swe znaczenie szczególnie w długim okresie i odzwierciedlają się często w perspektywach rozwojowych organizacji. Niestety, wraz z nimi i w podobnych warunkach, co wynika z zaprezentowanego modelu zależności, pojawiaja się także zadania niewymierne o charakterze pozornym. Są one nieomal nierozdzielnie ze sobą związane. Przyzwolenie kierownictwa na realizację zadań niemierzalnych w ogóle rodzi też pewna grupę, zapewne znaczną, działań niemierzalnych i jed-

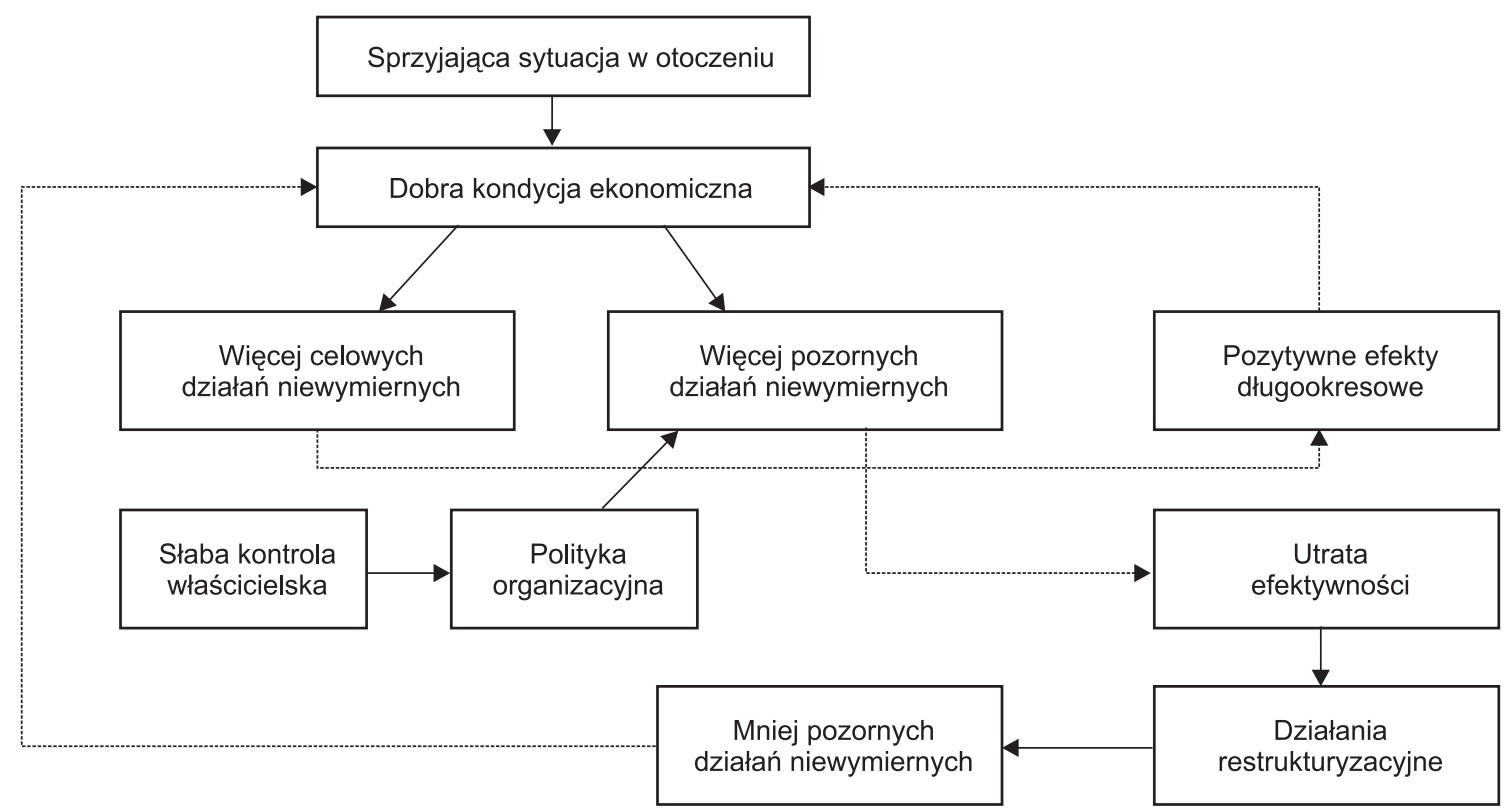

Rys. Układ zależności przedstawiający zjawisko narastania liczby działań z efektem niewymiernym i jego wpływ na efektywność organizacyjną

Źródło: opracowanie własne. 
nocześnie pozornych. Czasami sytuacja taka, co pokazano wyżej, leży w interesie samej kadry kierowniczej. Powyższe konstatacje nie mogą jednak prowadzić do wniosku, że zadania niemierzalne są złem koniecznym. Wprawdzie „ciągną” one za sobą zadania pozorne, lecz również stymulują rozwój. Stwierdziliśmy wyżej, że w warunkach „szczodrego" otoczenia i dobrej kondycji ekonomicznej pojawia się więcej zadań niemierzalnych, pojawia się bowiem resource slack, rezerwy organizacyjne. Na ogół resource slack jest dodatkowo charakterystyczny dla firm dużych. One też wprowadzają częściej w życie pewne jakościowo nowe i realnie postępowe rozwiązania. Stają się wówczas kopiowanym przykładem i swoistą forpoczta nowych wzorców działania. Przykładowymi przedsiębiorstwami tej grupy są chociażby ABB, Intel czy Virgin Group. Pełnią więc w długim okresie funkcję modyfikująca reguły organizacyjne firm w całej ich populacji ${ }^{8}$. Firmom małym, szczególnie w sektorach o znacznej konkurencji i zdominowanych przez podmioty będące wyłączną własnością prywatną, pozostaje raczej rola „organizacji szczupłych”, ogołoconych ze wszelkich przejawów niewymiernych nowości.

\section{Wnioski}

Tonkluzji można stwierdzić, że:

1 Firmy działające w warunkach konkurencyjnych branż koncentrują swą uwagę na działaniach operacyjnych, w ramach których dominuja działania $\mathrm{z}$ efektem wymiernym. W ten sposób firmy optymalizują bieżącą efektywność ekonomiczną. Efektem jest budowanie organizacji prostych, wręcz trywialnych, w których pozostaje niewiele miejsca na wszelkiego rodzaju eksperymenty społeczne oraz tzw. miękkie, planowo wdrażane metody zarządzania.

- Realizacja działań bez wymiernych efektów ma dualny charakter oddziaływania, pozytywny i negatywny zarazem. Z jednej strony, co dotyczy realnych i celowych działań, kreuje szanse dla organizacji w przyszłości, z drugiej, w efekcie realizacji działań pozornych, degraduje bieżącą efektywność ekonomiczną. Najprawdopodobniej akceptacja dla realizacji działań niewymiernych i zarazem celowych pociąga za sobą pojawianie się działań pozornych.
Tylko część organizacji, tych w bardzo dobrej kondycji ekonomicznej realizuje wdrożenia nowoczesnych metod zarządzania, a więc decyduje się na wiele działań, których całościowe efekty trudno oszacować. Moga one zwrotnie wspierać efektywność, lecz jej silnie nie determinują. Metody takie pojawiają się wówczas w postaci zredukowanej do najbardziej oczywistych elementów, generujących pewien jakościowy postęp. Wdrażanie opisywanych metod w przedsiębiorstwach słabych może być symptomem toczącej się w nich gry z podtekstem partykularnych interesów.

- W naukach organizacji i kierowania większą wage niż dotąd należy przywiązywać do badania tego ,jak jest”, w stosunku do tego ,jak być powinno”. Poznanie realiów i mechanizmów nimi rządzących może być pierwszym krokiem do realnego wpływu na bieg wydarzeń.

dr Krzysztof Łobos

Katedra Strategii i Metod Zarządzania Instytut Organizacji i Zarządzania

\section{PRZYPISY} Akademii Ekonomicznej we Wrocławiu

1) $\mathrm{W}$ warunkach niepatologicznych, tj. warunkach realnej realizacji celów ekonomicznych przedsiębiorstwa przy racjonalnie zaangażowanych zasobach, w tym ludzkich.

2) Koncepcja Nilsa Brunnsona na podstawie Mary Jo HATCH, Teoria organizacji, PWN, Warszawa, 2002, s. 278-280.

3) K. ŁOBOS, Izomorfia rozwiazań strukturalnych przedsiębiorstw $z$ pozycji teorii instytucjonalnej, ewolucyjnej oraz sytuacyjnej organizacji, „Organizacja i Kierowanie”, nr 3 (109)/2002, s. 20 i dalsze.

4) K. ŁOBOS, Determinizm czy swoboda wyboru strategicznego - integrujacy model W.F. Joyce'a i L.G. Hrebiniaka, [w:] R. KRUPSKI (red.), Zarzadzanie strategiczne. Koncepcje, metody, Wyd. AE we Wrocławiu, Wrocław 2001, s. 27.

5) A. GEORGES, L. ROMME, Self-Determination and Circular Organizing, „Organization Studies”, nr 20/5, 1999, s. 801 i dalsze.

6) T. GRUSZECKI, Wspótczesne teorie przedsiębiorstwa, PWN, Warszawa 2002, s. 181-184.

7) R. MARTIN, Politicized Managerial Capitalism: Enterprise Structures in Post-socialist Central and Eastern Europe, „Journal of Management Studies”, 39/6/2002, s. 827 i dalsze.

8) D. BUTCHER, M. CLARKE, Organizational Politics: The Cornerstone for Organizational Democracy, „Organizational Dynamics", 31/1/2002, s. 44. 